\title{
THE EFFECT OF HYGROMYCIN ON REGENERATION IN DIFFERENT ALSTROEMERIA EXPLANT TYPES AFTER AGROBACTERIUM-MEDIATED TRANSFORMATION
}

\author{
J.B. Kim, M.J. de Jeu, C.J.J.M Raemakers, E. Jacobsen, and R.G.F. Visser \\ Laboratory of Plant Breeding, \\ The Graduate School of Experimental Plant Sciences, \\ Wageningen University \\ P.O.BOX 386 \\ 6700 AJ, Wageningen, \\ The Netherlands \\ jong-bo.kim@pv.dpw.wag-ur.nl
}

Keywords: friable embryogenic callus, GUS, leaves with axils, monocot, organogenic tissue, somatic embryo

\begin{abstract}
$\underline{\text { Abstract }}$
This is the first successful report of Agrobacterium-mediated transformation in Alstroemeria by infection of FEC (Friable Embryogenic Callus) lines and leaves with axil tissues. Of the transformation methods, particle bombardment and Agrobacteriummediated transformation have been widely used to transfer foreign DNA into the plant genome. Especially, Agrobacterium tumefaciens efficiently infects most plants. Most monocotyledonous plants, including Alstroemeria, are recalcitrant to A. tumefaciens infection. Therefore, it is essential to develop an efficient, reliable protocol for Agrobacterium-mediated transformation in Alstroemeria. In order to achieve this aim, different hygromycin concentrations in selection medium were tested and compared in FEC explants and leaves with axil tissues using Agrobacterium strain LBA4404 (pTOK233). As a result, $20 \mathrm{mg} / \mathrm{l}$ hygromycin was a proper concentration to select for both FEC lines and leaves with axil tissues. Using this concentration, transformed lines were obtained. Moreover, FEC lines showed at least 2.5 times higher rate in the survival rate, and 5 times higher rate in transient GUS gene expression than those of leaves with axil tissues. The protocol, seems to be a promising method for the transformation of the monocot Alstroemeria with genes of interest in the near future.
\end{abstract}

\section{Introduction}

Alstroemeria is a perennial crop mainly cultured in greenhouses for cut flower production (Lin et al., 2000a). This vegetatively propagated ornamental cut flower has become highly popular in many countries within a short period (Buitendijk, 1998). The huge variation in the genus Alstroemeria provides a lot of opportunities for the improvement and renewal of the cultivar assortment. In order to introduce this genetic variation into different noncrossing species, genetic modification methods can be used for the Alstroemeria breeding program. Amongst many other agricultural traits, virus resistance will be a first target because infection with viruses can cause severe damage and many cultivars lack resistance to it (Bouwen and Van der Vlugt, 1996). However, although transformation in Alstroemeria has been described by Lin et al. (2000b), it is not yet a routine method, due to the low frequencies of regeneration and transformation using the present protocols. Meristem culture has been used to produce clean plant material. However, the risk of re-infection still remains (Van Zaayen et al., 1992). Genetic transformation, therefore, may be a way to develop virus resistant lines. In the method described by Lin et al. (2000b), particle bombardment was used as gene transfer method. Unfortunately, the efficiency of this method is rather low. Therefore, it was investigated 
whether the efficiency could be increased by using Agrobacterium tumefaciens as gene transfer method. Furthermore, Agrobacterium-mediated transformation was applied on an embryogenic and the organogenic regeneration system. Additionally, some fundamental aspects of transformation (selective antibiotic concentration, explant type to be used and other physiological parameters) were assessed and based upon that a standard method for A.tumefaciens transformation was established.

\section{Materials and methods}

\subsection{FEC induction from leaves with axil tissues and its regeneration}

Friable embryogenic calli (FEC) were initiated from leaves with axil of in vitro grown Alstroemeria cultivar VV024. From each shoot, leaves with axil tissues were cut using the method of Lin et al. (1997). Isolated explants were placed on shoot induction medium (SIM) containing MS (Murashige and Skoog, 1962) basal salts and vitamins, 30 $\mathrm{g} / \mathrm{l}$ sucrose, $2.2 \mathrm{mg} / \mathrm{l} \mathrm{TDZ}, 0.1 \mathrm{mg} / \mathrm{l} \mathrm{IBA}$, solidified with $7.5 \mathrm{~g} / \mathrm{l}$ microagar at $\mathrm{pH} 6.0$, and cultured in the dark for 10 days. After that, the explants were transferred to callus induction medium (CIM) containing MS medium, supplemted with $2 \mathrm{mg} / \mathrm{l}$ 2,4-D, 0.5 $\mathrm{mg} / \mathrm{l} \mathrm{BA}, 30 \mathrm{~g} / \mathrm{l}$ sucrose, solidified with $7.5 \mathrm{~g} / \mathrm{l}$ micro agar, $\mathrm{pH}$ 6.0. After 68 weeks of culture on CIM, yellow compact calli were found with friable embryogenic callus (FEC) clumps on the surface. The FEC clumps were isolated of the compact calli, and maintained on PCA medium (Sofiari et al., 1998) and subcultured every four weeks. Cultured FEC clumps were transferred to regeneration medium (RM) containing $0.5 \mathrm{mg} / \mathrm{l}$ $\mathrm{BA}, 40 \mathrm{~g} / \mathrm{l}$ sucrose, solidified with $2.5 \mathrm{~g} / \mathrm{l}$ Gelrite, $\mathrm{pH} 6.0$ for regeneration. After 4-6 weeks of incubation under a $16 / 8 \mathrm{~h}$ (light/dark) photoperiod at $18^{\circ} \mathrm{C}$, production of somatic embryos were observed on the surface of yellow FEC clumps. Then, somatic embryos were isolated and subcultured on fresh RM media under the same culture condition every 4 weeks until shoots regenerated. Regenerated shoots $(2-3 \mathrm{~cm})$ were transferred to rooting medium containing $0.5 \mathrm{mg} / \mathrm{l} \mathrm{IBA}, 45 \mathrm{~g} / \mathrm{l}$ sucrose, solidified with 2.5 $\mathrm{g} / \mathrm{l} \mathrm{Gelrite}$, at $\mathrm{pH}$ 6.0.

\subsection{Induction of organogenic tissue and its regeneration}

Leaves with axil tissues were first cultured on shoot induction medium (SIM), and later, the explants were transferred to regeneration medium (RM); subcultured every 3 weeks.

\subsection{Influence of hygromycin concentration on regeneration}

FEC lines and leaves with axil tissues precultured for 10 days on SIM were transferred to regeneration medium containing $(0,1,5,10,20,30 \mathrm{mg} / \mathrm{l})$ hygromycin in order to determine the proper dose of selectable agent for the transformation protocol. After 6 weeks of culture on selection medium, survival rates of explants and browning level were measured.

2.4. Agrobacterium-mediated transformation of Alstroemeria using FEC lines and organogenic tissue.

Three week old FEC lines (Fig. 1a) and leaves with axil tissues precultured for 10 days on SIM medium were infected with Agrobacterium tumefaciens strain LBA4404 (pTOK233). The strain contains the uidA reporter gene and the hpt and nptII selectable genes (Hiei et al., 1994). The strain was grown in Luria Broth (LB) medium for 24 hours at $30^{\circ} \mathrm{C}$. Prior to inoculation, bacterial cultures were centrifuged at 3,000 rpm for $10 \mathrm{~min}$. The pellet was first re-suspended in N6 (Chu et al., 1975) liquid medium. Then, the suspension was diluted 1:50 in MS liquid medium at an optical density of $0.7\left(\mathrm{O}_{600 \mathrm{~nm}}\right)$. 
FEC (250 mg) and leaves with axil tissue precultured for 10 days on SIM were imersed in this bacterial suspension for $10 \mathrm{~min}$, blotted dry on sterile filter paper, and cultured on regeneration medium in the dark. After 3 days, the explants were first washed with liquid regeneration medium supplemented with $300 \mathrm{mg} / \mathrm{l}$ cefotaxime and $250 \mathrm{mg} / \mathrm{l}$ vancomycin, and then, placed on regeneration medium supplemented with $200 \mathrm{mg} / \mathrm{l}$ cefotaxime, 100 $\mathrm{mg} / \mathrm{l}$ vancomycin, and $20 \mathrm{mg} / \mathrm{l}$ hygromycin. After 4 weeks of culture, hygromycin concentration was lowered to $7.5 \mathrm{mg} / \mathrm{l}$ and after 12 weeks to $2.5 \mathrm{mg} / \mathrm{l}$. Leaves with axil tissues were first cultured on regeneration medium supplemented with $40 \mathrm{~g} / \mathrm{l}$ sucrose, 200 $\mathrm{mg} / \mathrm{l}$ cefotaxime, $100 \mathrm{mg} / \mathrm{l}$ vancomycin, and $10 \mathrm{mg} / \mathrm{l}$ hygromycin. After 6 weeks, the hygromycin concentration was lowered to $2.5 \mathrm{mg} / \mathrm{l}$. These cultures were maintained at $18^{\circ} \mathrm{C}$ with a 16-h photoperiod, and subcultured every 3-4 weeks to fresh selection medium. After 6 weeks of culture, GUS expression and transformation efficiencies were assayed. To calculate transformation efficiency the explants which survived on selection medium were assayed for GUS activity, and the number of GUS positive explants were divided by the total number of inoculated explants.

\subsection{Histochemical GUS assay of mature somatic embryos and plants}

The gus assays were accomplished using the method of Jefferson et al. (1987) with 4 week intervals. No GUS activity was detected in non-transformed callus and regenerated plants of VV024.

\section{Results}

FEC lines and leaves with axil tissues were cultured on regeneration medium, supplemented with $(0,1,5,10,20,30 \mathrm{mg} / \mathrm{l})$ hygromycin. PTOK233 contains both npt II and $h p t$ as selectable marker genes. In previous experiment, it was shown that both FEC and leaves with axil tissue were resistant to high level $(200 \mathrm{mg} / \mathrm{l})$ of kanamycin (data not shown). Therefore, hygromycin was used as selective agent. In this experiment, all FEC clumps survived on a medium without hygromycin and the first somatic embryos (SE) appeard after 4 weeks of culture. In total, 376 SE were isolated from 96 clumps and cultured seperately for shoot development. The first shoots were formed after 7 weeks of culture. In total, 325 shoots were produced from 376 cultured SE after 10 weeks of culture. Medium supplemented with $1 \mathrm{mg} / \mathrm{l}$ hygromycin had an inhibitory effect on regeneration. Only $68 \%$ of the explants survived. The mean number of SE per explant was 1.56, compared to 3.91 for the treatment without hygromycin. In the treatment without hygromycin, almost all SE developed into shoots, whereas, with $1 \mathrm{mg} / \mathrm{l}$ hygromycin about $60 \%$ of the SE developed into shoots. Regeneration was almost completely blocked when $10 \mathrm{mg} / \mathrm{l}$ hygromycin was added to the regeneration medium. With a hygromycin concentration of $20 \mathrm{mg} / \mathrm{l}$, all the explants showed browning and died (Table 1).

In the case of leaves with axil tissues, all explants survived on a medium without hygromycin. After 5 weeks of culture, one explant could have formed up to 3-4 shoots. However, usually only one well-developed shoot was isolated and this one was transferred to regeneration medium for further growth. After 3-4 weeks of incubation on regeneration medium, they were transferred to rooting medium. After another 3-4 weeks of culture, $78 \%$ of cultured shoots had developed roots. However, $1 \mathrm{mg} / \mathrm{l}$ hygromycin reduced the percentage of surviving explants to $70 \%$. In the end, $78 \%$ of the 39 isolated shoot cluster parts were regenerated with one or more roots. Regeneration of leaves with axil tissues was possible up to $10 \mathrm{mg} / \mathrm{l}$ hygromycin in the medium, although $6 \%$ of the cultured explants were survived at $20 \mathrm{mg} / \mathrm{l}$ hygromycin, they did not regenerate plants (Table 2).

Based on the results, therefore, $20 \mathrm{mg} / \mathrm{l}$ of hygromycin was used for Agrobacterium-mediated transformation of FEC and leaves with axil parts. To establish an efficient transformation system using A. tumefaciens in Alstroemeria, first of all, the 
proper explant type should be determined. For this, 96 FEC clumps and 120 leaves with axil tissues were infected with LBA4404 (pTOK233). After the transformation, both explant types were cultured on regeneration medium containing $20 \mathrm{mg} / \mathrm{l}$ as a selectable marker. As a result, after 6 weeks of culture on selection medium, $28.1 \%$ of infected FEC clumps survived; whereas, $10.8 \%$ of infected leaves with axil tissues survived. All survived explants were screened for gus activity. For FEC clumps, 20 of 27 surviving FEC clumps were GUS positive (Fig. 1b); whereas, only 5 of 13 surviving leaves with axil explants were GUS positive (Fig. 1c). FEC samples stained completely blue, whereas organogenic tissue was only partly blue. Transformation efficiency (TE) was almost 5 times higher with FEC than with leaves with axil tissue (Table 3).

\section{Discussion}

For improving a crop by using genetic transformation, several parameters should be optimised. Amongst others, these are an efficient DNA delivery system, appropriate target cells with regeneration capacity, adequate promoter for stable gene expression, and a efficient selection system (Christou, 1995; Hiei et al., 1994, 1997; Smith and Hood, 1995). Agrobacterium-mediated transformation was more efficient as compared to particle bombardment (data not shown). This was also shown in other monocot plants such as rice (Hiei et al., 1994, 1997), sugarcane (Arencibia et al., 1998), and Sorghum (Zhao et al., 2000). In monocot transformation, embryogenic callus and meristemetic tissue have been mainly used. Here, 2 explants types; fec and organogenic tissues, were compared. In Alstroemeria, transgenic tissues were produced by cocultivation of both friable embryogenic callus (FEC) lines and leaves with axil tissues with Agrobacterium tumefaciens. However, the transformation efficiency of FEC was almost 5 times higher than that of leaves with axil. Furthermore, the appearance of only partly blue colored parts in the organogenic system suggest that the plants are not completely transformed. In later experiments, it was shown that transgenic FEC yielded completely blue staining plants. From these results, it can be concluded that only FEC can yield completely transgenic plants. Most probably, this is because FEC explants is a more active dividing tissue compared to leaves with axil tissue. In the experiments described here, the gus and $h p h$ genes were driven by the $35 \mathrm{~S}$ promoter. In previous studies, no significantly differences were found between $35 \mathrm{~S}$ and ubiquitine promoter in particle bombardment of Alstroemeria. This report was focused on the development of Agrobacterium-mediated transformation protocol by the improvement of the selection process. The selective agent, hygromycin was used here because Alstroemeria FEC survived at 75 or $100 \mathrm{mg} / \mathrm{l}$ of kanamycin and even showed regeneration. With hygromycin, it was possible to select transgenic tissue or plant from FEC. A similar result was found in the monocot forage grass (Franklin et al., 1990). Additionally, the results reported here were obtained with only one bacterial strain. Unfortunately, this srain LBA4404 (pTOK233) can not be used for the transfer of gene of interests as it lacks unique restriction sites. It is believed that in the near future further progress will be made using other Agrobacterium tumefaciens strains. This will be accomplished by selection of the proper bacteria strain, and concentration, explant genotype, infection time, the effect of acetosyringone, cocultivation period, and dilution of bacterial suspension culture (Birch, 1997; Van Wordragon and Dons, 1992). This protocol will then be used for the development of virus resistance plants in Alstroemeria.

\section{$\underline{\text { Acknowledgements }}$}

The Alstroemeria plants of VV024 were kindly provided by Van Staaveren (the Netherlands). This research was partly financed by the Ministry of Education, Republic of Korea. 


\section{References}

Arencibia A.D., Carmona E.R., Tellez P., Chan M.T., Yu S.M., Trujillo L.E. and Oramas, P., 1998. An efficient protocol for sugarcane (Saccharum spp. L.) transformation mediated by Agrobacterium tumefaciens. Transgenic Research 7: 213-222.

Birch R.G., 1997. Plant transformation: problems and strategies for practical applications. Annual Review Plant Physiology Plant Molecular Biology 48:297-326.

Bouwen I., and Van der Vlugt R.A.A., 1996. Identification and characterization of potyviruses of Alstroemeria spp. Acta Horticulturae 432:72-74.

Buitendijk J.H., 1998. A cytological characterization of genomes of Alstroemeria, the production of interspecific hybrids, and their performance during micropropagation. Ph.D. thesis. Wageningen Agricultural University, Wageningen, Netherlands.

Christou P., 1995. Strategies for variety-independent genetic transformation of important cereals, legumes and woody species utilizing particle bombardment. Euphytica 85: 13-27.

Chu C.C., Wang C.C., Sun C.S., Hsu C., Yin K.C., Chu C.Y., and Bi F.Y., 1975. Establishment of an efficient medium for anther culture of rice through comparative experiments of the nitrogen sources. Scientia Sinica 18:659 - 668.

Franklin C.I., Trieu T.N., and Gonzales, R.A., 1990. Plant regeneration through somatic embryo genesis in the forage grass Caucasian bluestem (Bothriochloa caucasica). Plant Cell Reports 9:443-446.

Hiei Y., Ohta S., Komari T., and Kumashiro T., 1994. Efficient transformation of rice (Oryza sativa L.) mediated by Agrobacterium and sequence analysis of the boundaries of the T-DNA. Plant Journal 6:271-282.

Hiei Y., Komari T., and Kubo T., 1997. Transformation of rice mediated by Agrobacterium tumefaciens. Plant Molecular Biology 35:205-218.

Jefferson R.A., Kavanagh T.A., and Bevan M.W., 1987. GUS fusions: $\beta$-glucuronidase as a sensitive and versatile gene fusion marker in higher plants. EMBO Journal 6:39013907.

Lin H.S., De Jeu M.J., and Jacobsen E., 1997. Direct shoot regeneration from excised leaf explants of in vitro grown seedlings of Alstroemeria L. Plant Cell Reports 16:770774.

Lin H.S., De Jeu M.J., and Jacobsen E., 2000a. The application of leafy explant micropropagation protocol in enhancing the multiplication efficiency of Alstroemeria. Scientia Horticulturae 85:307-318.

Lin H.S., Van der Toorn.C., Raemakers C.J.J.M., Visser R.G.F., De Jeu M.J., and Jacobsen E., 2000b. Genetic transformation of Alstroemeria using particle bombardment. Molecular Breeding 6:369-377.

Murashige T., and Skoog F., 1962. A revised medium for rapid growth and bioassays with tobacco tissue cultures. Plantarium Physiology 15:473-497.

Smith R.H., and Hood E.E., 1995. Agrobacterium tumefaciens transformation of monocotyledons. Crop Science 35:301-309.

Sofiari E., Raemakers C.J.J.M., Bergervoet J.E.M., Jacobsen E., and Visser R.G.F., 1998. Plant regeneration from protoplasts isolated from friable embryogenic callus of cassava. Plant Cell Reports 18:159-165.

Van Wordragon M.F., and Dons H.J.M., 1992. Agrobacterium tumefaciens-mediated transformation of recalcitrant crops. Plant Molecular Biology Reporter 10:12-35.

Van Zaayen A., Van Eijk C., and Versluijs J.M.A., 1992. Production of high quality, healthy ornamental crops through meristem culture. Acta Bot. Neerland. 41:425-433.

Zhao Z.Y., Cai T., Tagliani L., Miller M., Wang N., Pang H., Rudert M., Schroeder M., Hondred D., Seltzer J., and Pierce D., 2000. Agrobacterium-mediated sorghum transformation. Plant Molecular Biology 44:789-798. 
Table 1. Effect of different hygromycin concentrations on survival rate, browning level, somatic embryo induction and shoot regeneration capacity of FEC in VV024 of Alstroemeria.

\begin{tabular}{ccccc}
\hline $\begin{array}{c}\text { Hygromycin } \\
(\mathrm{mg} / \mathrm{l})\end{array}$ & $\begin{array}{c}\text { \# of survived } \\
\text { explants }(\%)^{*}\end{array}$ & $\begin{array}{l}\text { Level of } \\
\text { browning* }\end{array}$ & $\begin{array}{l}\text { \# of somatic } \\
\text { embryos* }\end{array}$ & $\begin{array}{c}\text { \# of regenerated } \\
\text { shoots** }\end{array}$ \\
\hline Control & $96(100)$ & - & 376 & 325 \\
1 & $65(67.7)$ & + & 102 & 61 \\
5 & $22(22.9)$ & ++ & 16 & 3 \\
10 & $9(9.4)$ & +++ & 4 & 0 \\
20 & $0(0)$ & +++ & 0 & 0 \\
30 & $0(0)$ & +++ & 0 & 0 \\
\hline
\end{tabular}

* Data are collected after 6 weeks culture on selection medium.

** Data are collected after 12 weeks culture on selection medium

Table 2. Effect of different hygromycin concentrations on survival rate, browning level, shoot induction and regeneration capacity of leaves with axil tissues in VV024 of Alstroemeria.

\begin{tabular}{ccccc}
\hline $\begin{array}{c}\text { Hygromycin } \\
(\mathrm{mg} / \mathrm{l})\end{array}$ & $\begin{array}{c}\text { \# of survived } \\
\text { explants (\%)* }\end{array}$ & $\begin{array}{l}\text { Level of } \\
\text { browning* }\end{array}$ & $\begin{array}{l}\text { \# of explants } \\
\text { with shoots* }\end{array}$ & $\begin{array}{l}\text { \% of rooting } \\
\text { selected shoots** }\end{array}$ \\
\hline Control & $50(100)$ & - & 39 & 78 \\
1 & $35(70)$ & + & 24 & 48 \\
5 & $22(44)$ & ++ & 7 & 14 \\
10 & $9(18)$ & ++ & 3 & 6 \\
20 & $3(6)$ & +++ & 0 & 0 \\
30 & $0(0)$ & +++ & 0 & 0 \\
\hline
\end{tabular}

* Data are collected after 6 weeks culture on selection medium.

** Data are collected after 12 weeks culture on selection medium 
Table 3. Transformation of FEC and leaves with axil tissues of Alstroemeria c.v. VV024 with Agrobacterium strain LBA4404 (pTOK233). These experiments were repeated four times.

\begin{tabular}{lcccc}
\hline $\begin{array}{l}\text { Explant } \\
\text { Types }\end{array}$ & $\begin{array}{l}\text { \# of inoculated } \\
\text { explants }\end{array}$ & $\begin{array}{l}\text { \# of hygromycin } \\
\text { positive explants } \\
(\%)^{\mathrm{a}}\end{array}$ & $\begin{array}{l}\text { \# of positive } \\
\text { explants in } \\
\text { GUS }(\%)^{\mathrm{a}}\end{array}$ & $\begin{array}{l}\text { Transformation } \\
\text { efficiency (TE) }\end{array}$ \\
\hline FEC line & 96 & $27 / 96(28.1)$ & $20 / 96(20.8)$ & $20 / 96(20.8)$ \\
$\begin{array}{l}\text { Leaves with } \\
\text { axil }\end{array}$ & 120 & $13 / 120(10.8)$ & $5 / 120(4.2)$ & $5 / 120(4.2)$ \\
\hline $\begin{array}{l}\text { a: Data collected 6 weeks after culture in survived explants via hygromycin selection. } \\
\text { b: TE = \# of explants positive for both } h p t \text { and gus / total number of explants. }\end{array}$
\end{tabular}

Figure 1. Transient GUS gene expression of Alstroemeria using LBA4404 (pTOK233).

a. Three week old FEC clumps used for transformation experiment

b. GUS gene expression in FEC line 2 weeks after cocultivation

c. GUS gene expression in leaves with axil tissue 2 weeks after cocultivation

a

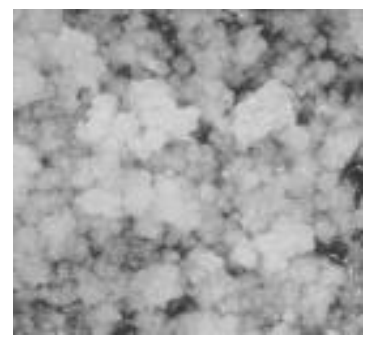



c

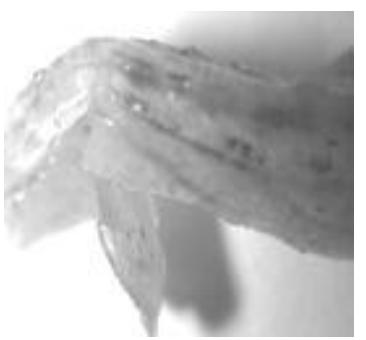

